\title{
The Impact of Engineering and Engineering Education
}

Economic and Functional Impacts

February 6, 2018

Simon Tripp, Principal and Senior Director - TEConomy Partners 

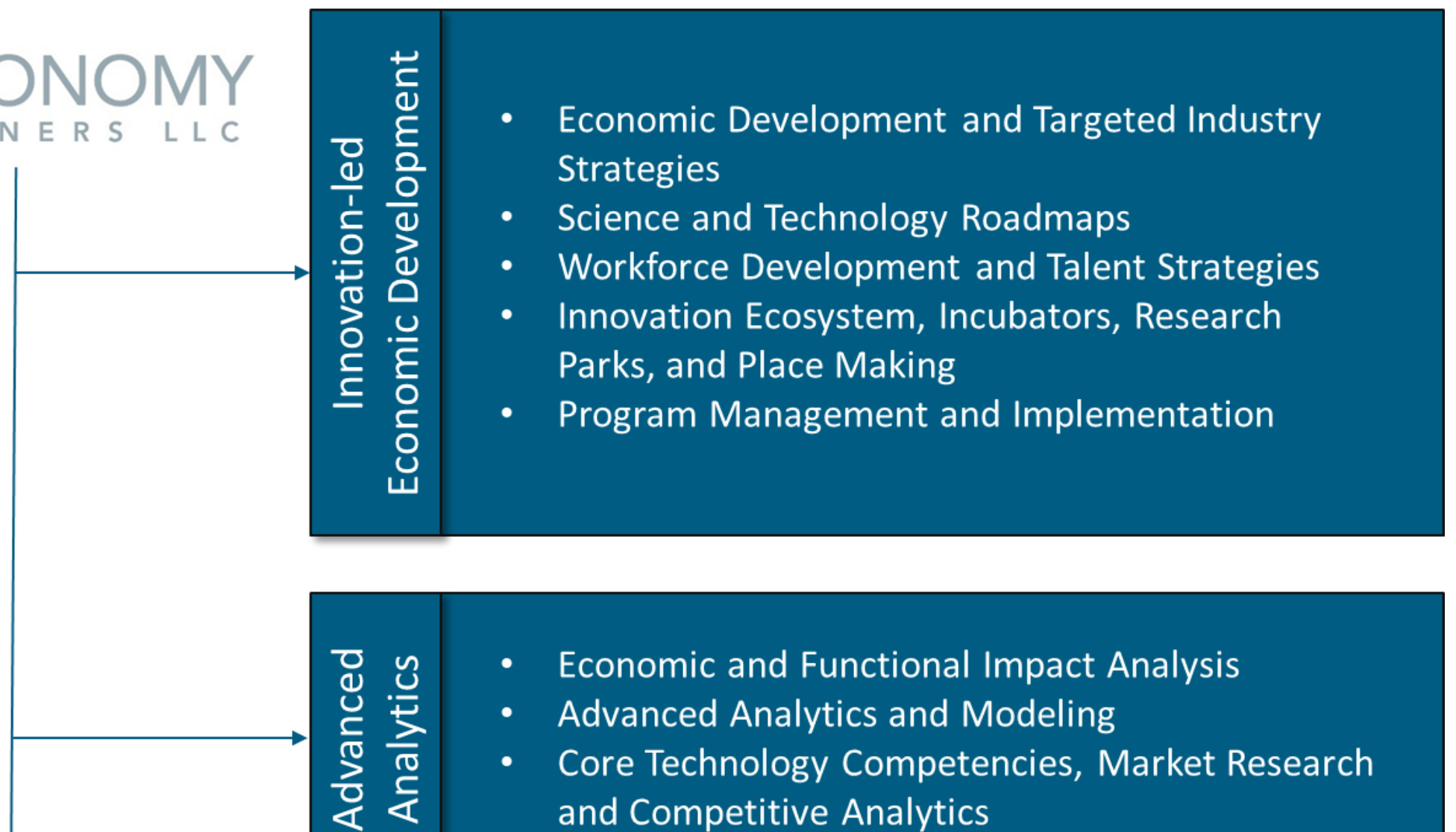

- Economic and Functional Impact Analysis

- Advanced Analytics and Modeling

- Core Technology Competencies, Market Research and Competitive Analytics

- Science and Technology Futures

- Program and Policy Evaluation

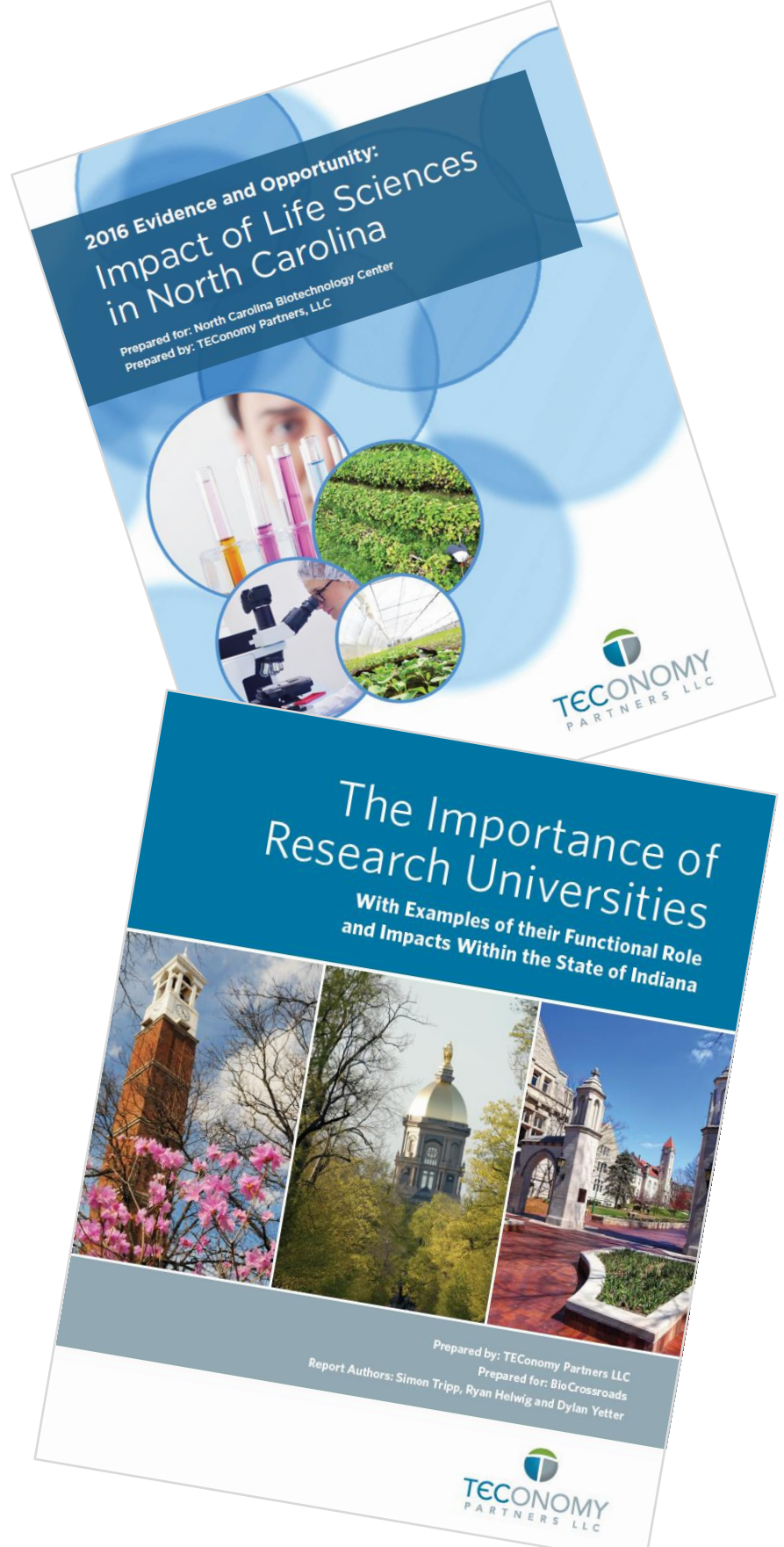


Some

Recent TEConomy Reports

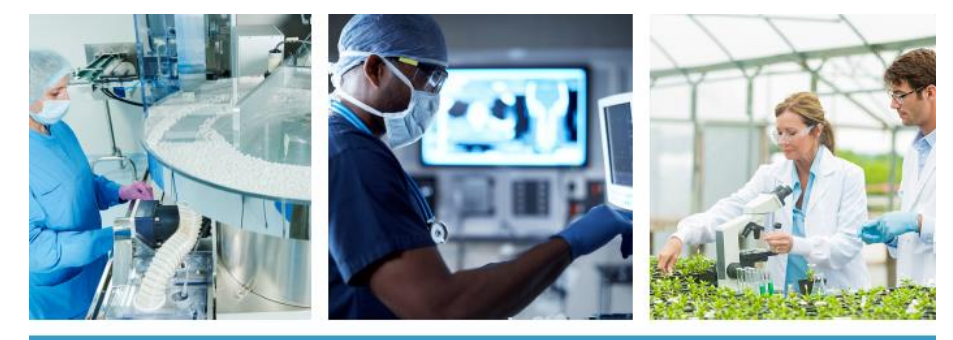

Assessing Washington's Life Science and Global Health Workforce Dynamics: Enhancing Connections and Addressing the Skills Gaps to Ensure Future Growth

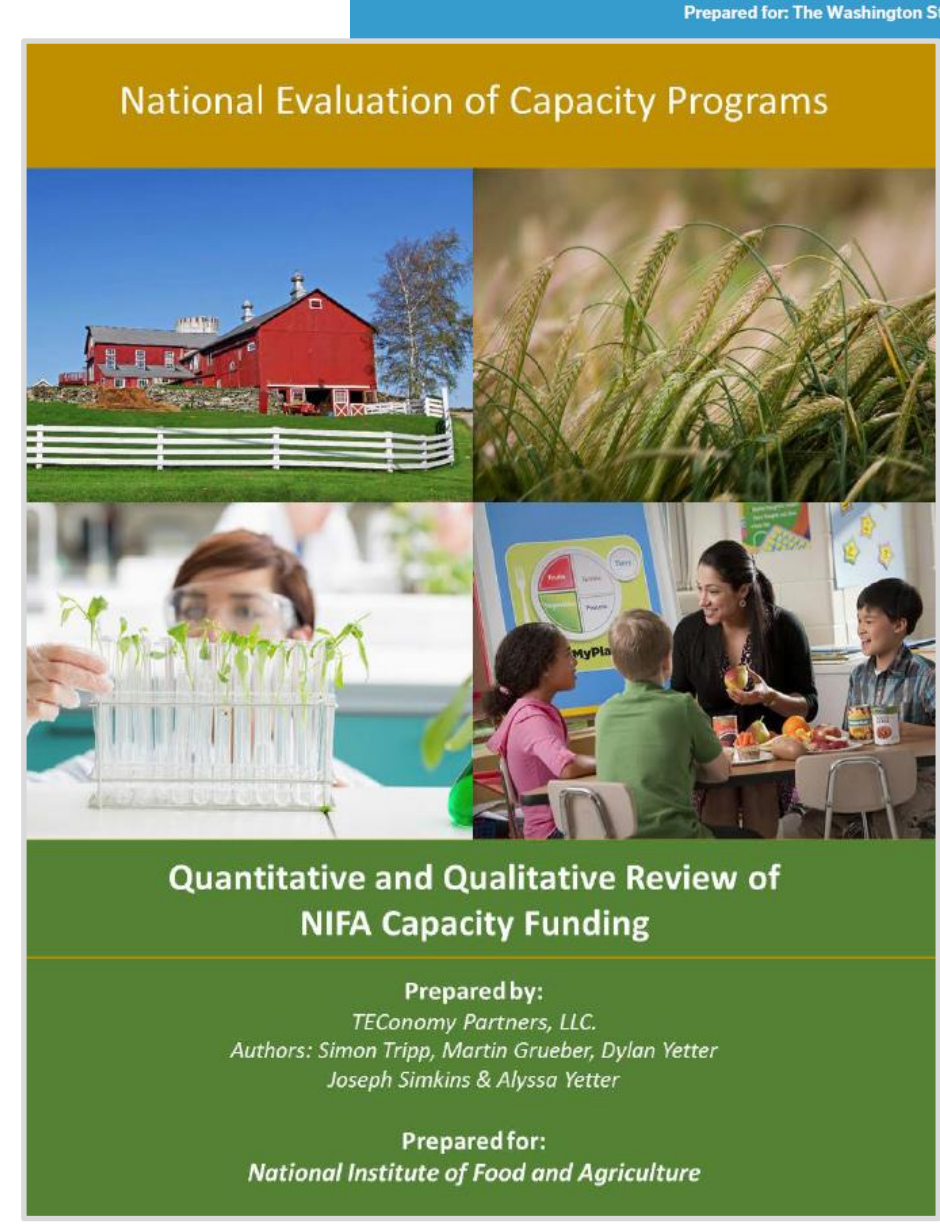

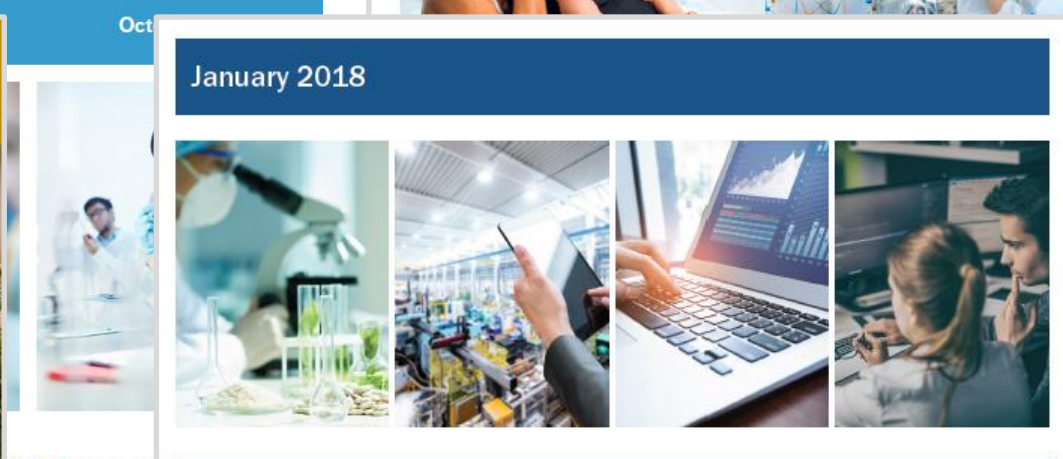

$\in C O N$

Assessment of Virginia's Research Assets:
Strategic Directions to Advance Innovation-Led Growth and HighQuality Job Creation across the Commonwealth

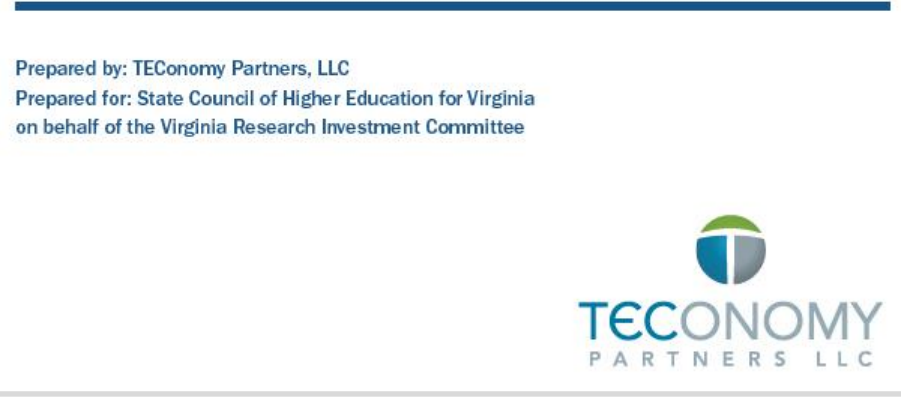

\section{Seizing a New Era of Medical Discovery:}

How Policymakers Can Embrace

Practical Ideas that Help Lead to

New Treatments and Cures
A Quantitative and Qualitative

Review of the Impacts of
University of Missouri Extension

UNIVERSITY OF MISSOURI

巴Extension

Improving the Lives of Patients and Growing the Economy
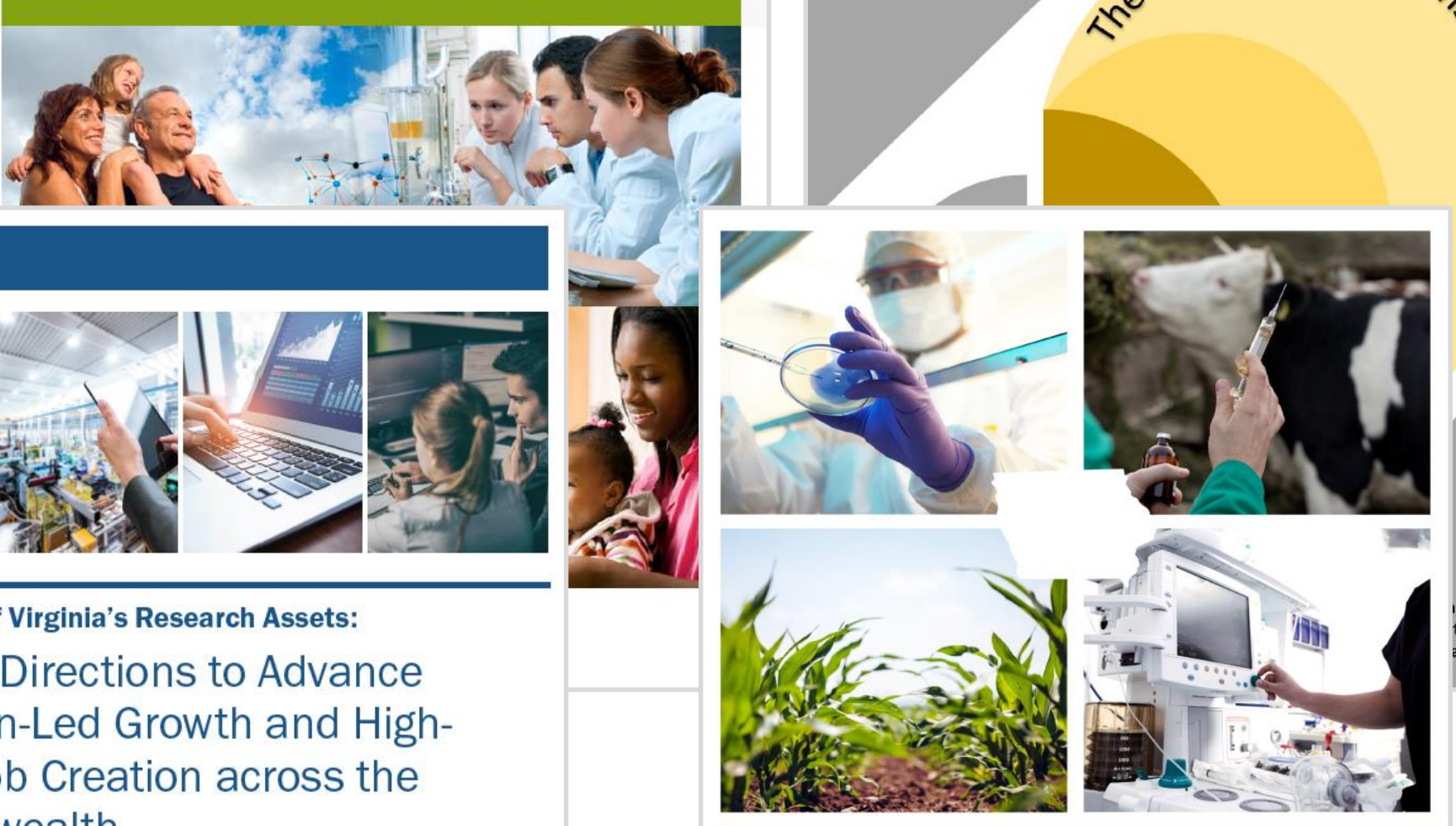

Phase II Report:

Strategies and Actions for lowa Bioscience Development. Crosscutting and Platform Specific Strategies and Actions.

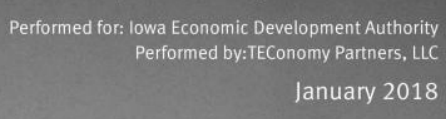

IC WA D T TERTNERS $L$ W 
- Projects for individual institutions, colleges and programs through to entire industries and sectors

- Universities: e.g. University of

TEConomy Partners Impact Analysis Practice Nebraska, Oklahoma State University, The Ohio State University, NC State, etc.

- Industries: e.g. Biotechnology, Pharmaceuticals, Industrial Physics, Clinical Genomics, Agriculture, Medical Devices, Recreation, Healthcare

- Major Initiatives \& Institutions: e.g. Human Genome Project, USDA Research Funding, Mayo Clinic

- TEConomy Partners was previously the Battelle Technology Partnership. Practice. Became independent in 2015.

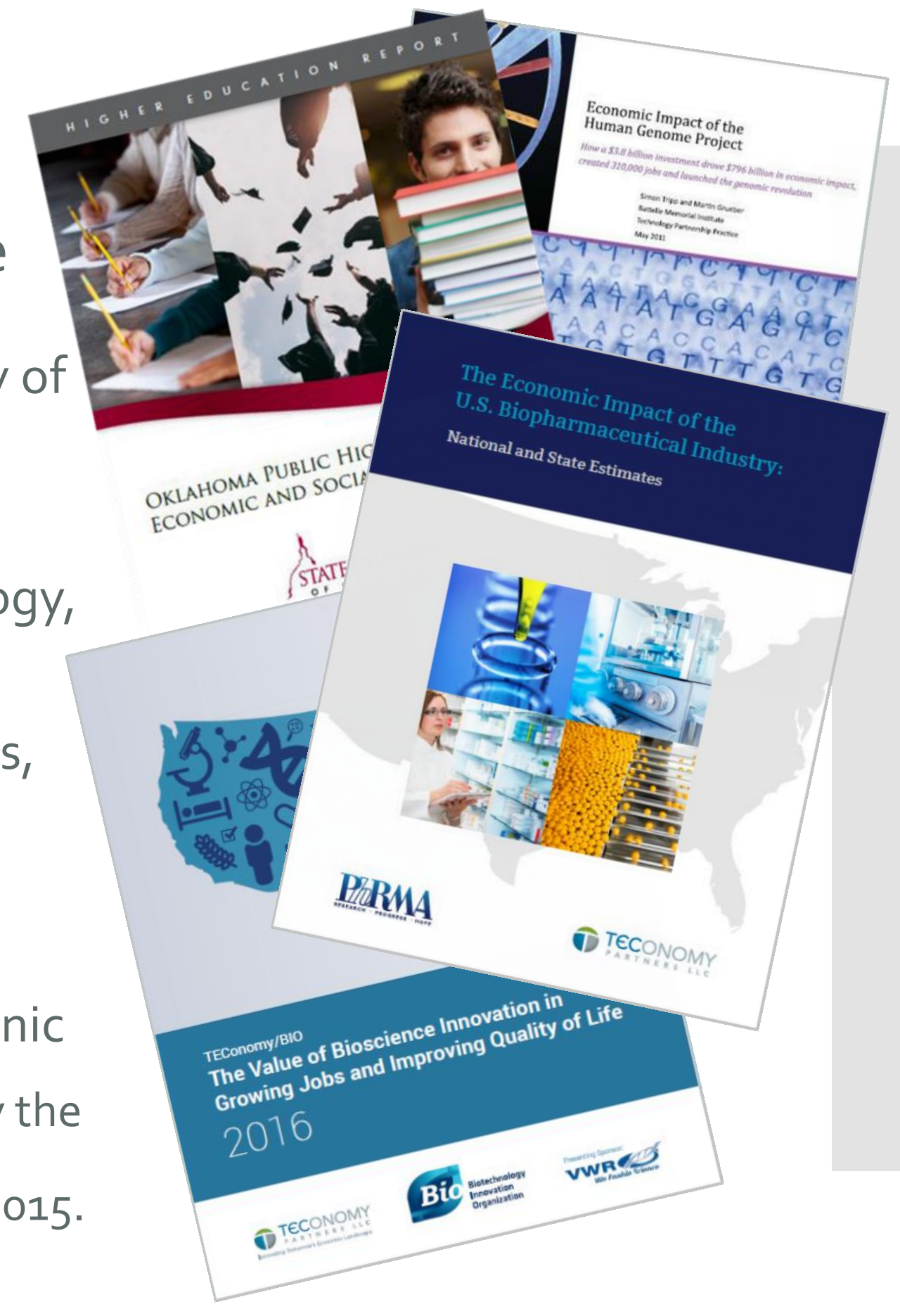




\section{University locations for core competency, strategic planning and impact analysis projects}

U Washington

$$
\text { WSU }
$$

u Oregon

OHSU

OSU

U Idaho

ISU

Boise State

UCLA

USC
Cal Tech

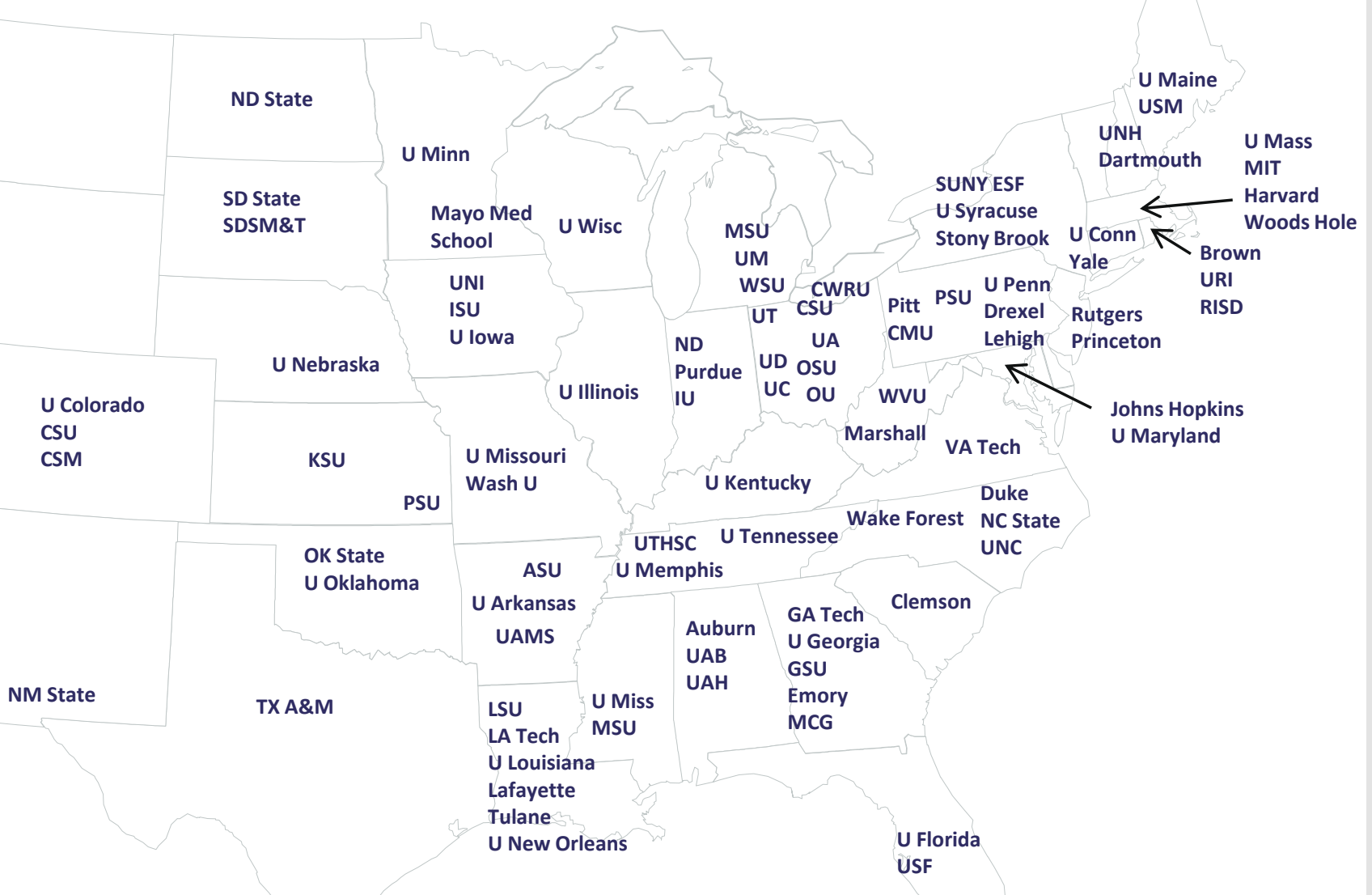




\section{What are the impacts of a College of Engineering?}


Recent research profiling the importance of research universities is directly relevant to our discussion today
- Explained university research in the context of the full-range of functions served by universities in modern society.

- Profiled the structure of modern university-based research, academic disciplines, and the increasing importance of transdisciplinary inquiry.

- Explored the impacts of research universities in terms of private and social returns and market and nonmarket returns.

- Discussed the changing environment for university research funding and structural changes taking place in academe resulting from technological, political, and societal trends.

- Worked towards developing a mutual understanding and appreciation of the importance of universities and university-based research in all its forms.
The Importance of Research Universities

With Examples of their Functional Role and Impacts Within the State of Indiana

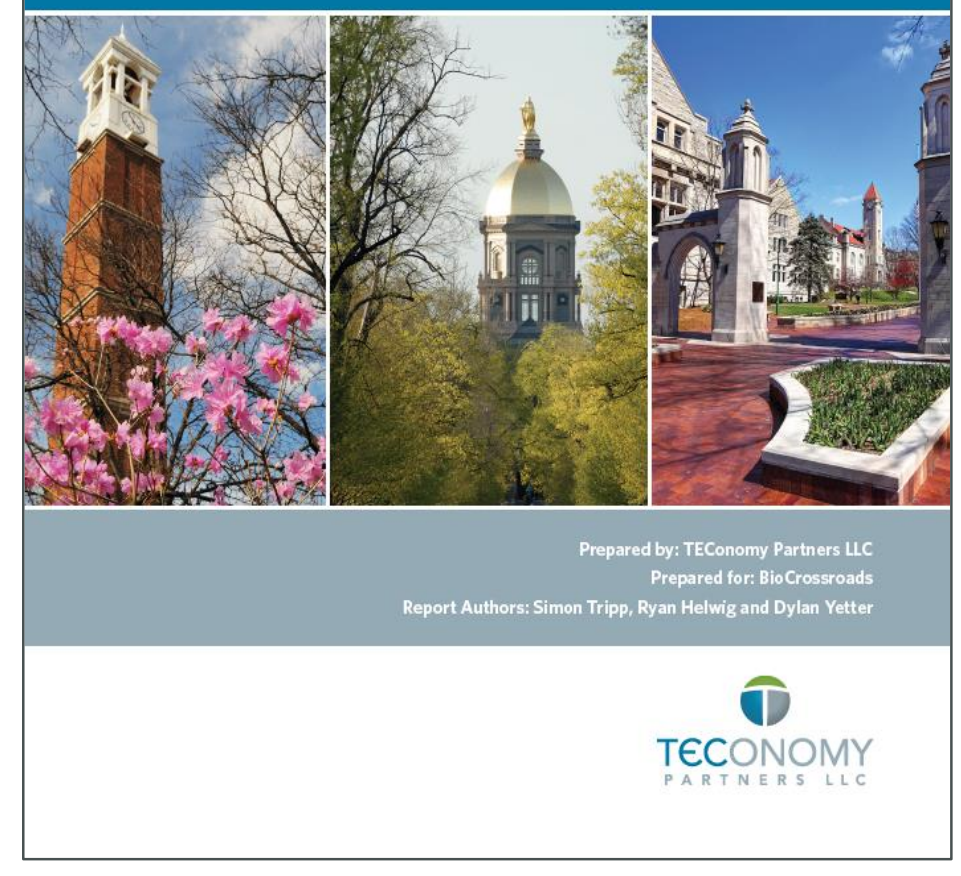

https://www.cicpindiana.com/ resources/importanceresearch-universities/ 


\section{The Functional Impacts of Research Universities.}

Towards a shared understanding of the benefits that accrue through wide-ranging university functions.

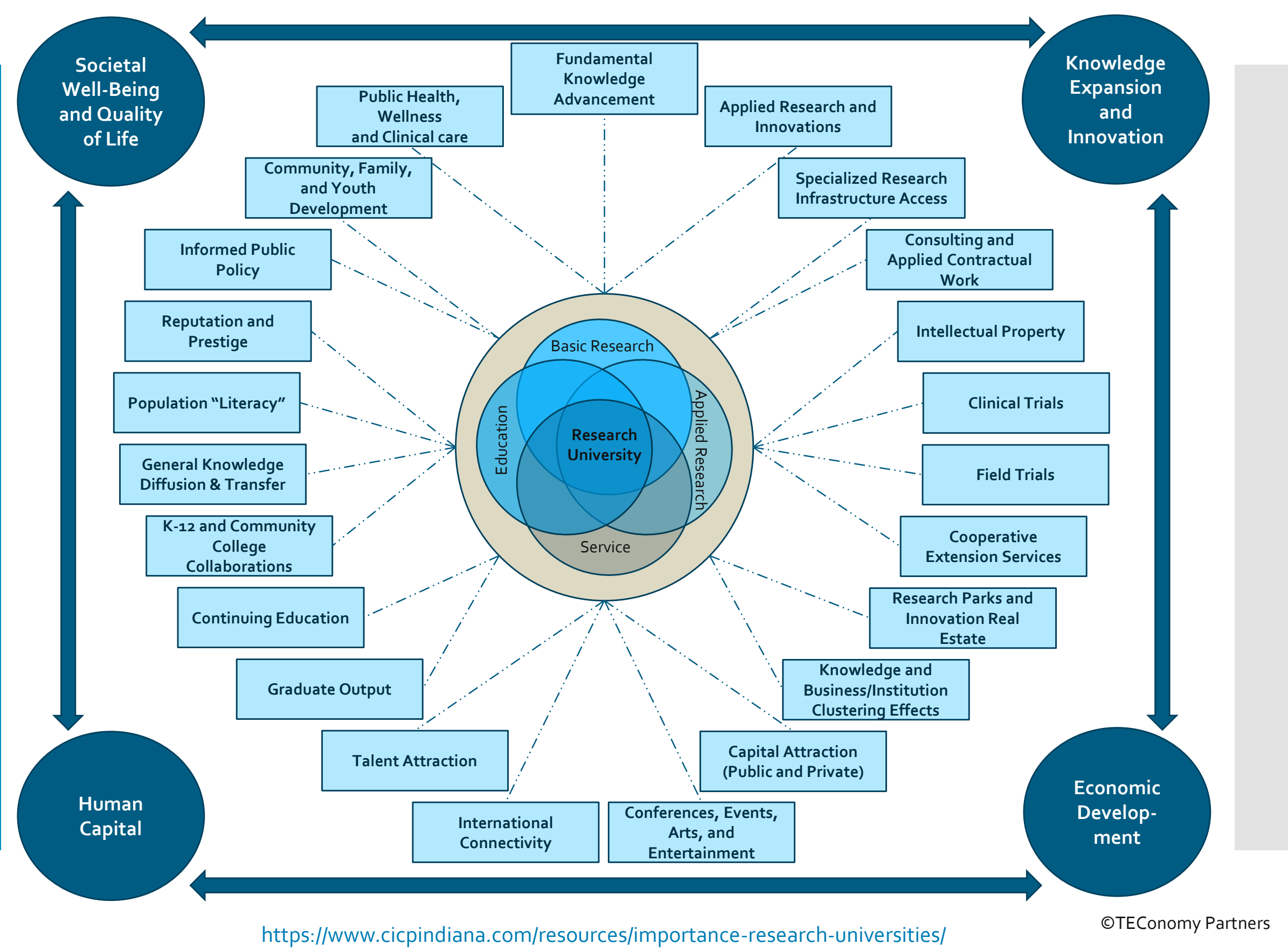




\section{SOCIAL}

\section{Impact Returns}

Social/Private \& Market/Non-Market Dimensions of Research University Impacts
NONMARKET

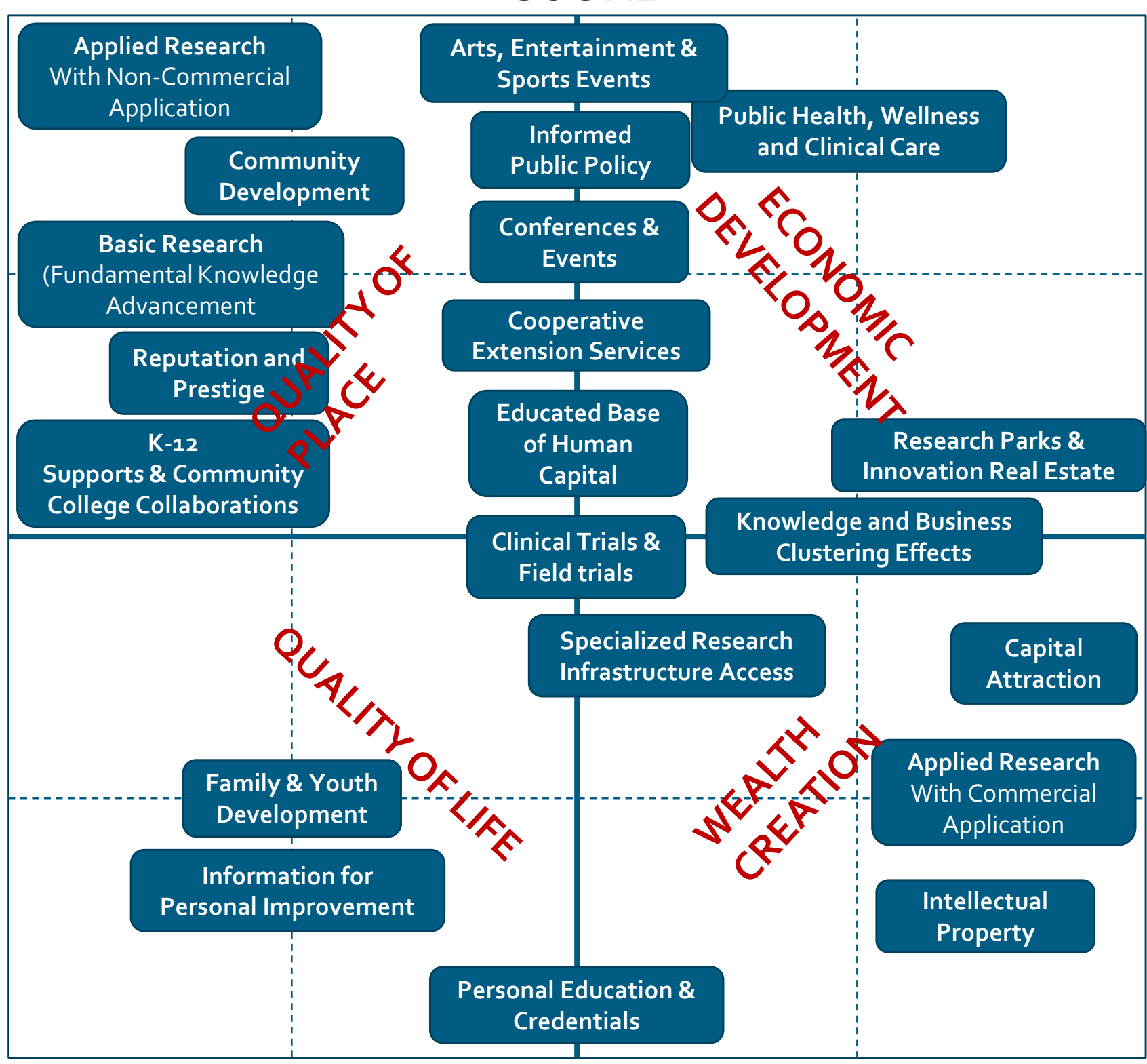

PRIVATE 
- Fundamental knowledge advancement: Innovating and developing the advanced instruments, sensors and tools that enable discovery. (Examples: Colliders, Sequencers, Imaging, High Performance Computing, Space Systems)

Some

Functional

Impact Areas

of Academic

Engineering
- Applied research and innovations: The heart of engineering

- Solutions to challenges - from "grand" to "local"

- Piloting, scale-up and commercialization

- Specialized Infrastructure

- Consulting and Expertise

- Extension solutions

- Knowledge and business clustering effects

- Talent attraction and development/human capital 


\section{Economic Development:}

Colleges of engineering are crucial to a complete economic development ecosystem
University role in

supporting recruitment of University R\&D and consulting

access to research support for existing businesses in the cluster, and support for University entrepreneurcapabilities, star faculty additional business growth

and talent

ship program

and

entrepreneurs-

in-residence.

University

incubators,

accelerators, partners committed

performed research, and

research infrastructure,

plus the attraction of

external funds to support

to translating

discovery into

application and
moving it towards

infrastructure commitment

and personnel to intellectu

$\begin{array}{ll}\text { to } & \text { property } \\ \text { testing } & \text { protection, }\end{array}$

technology technology

piloting and

piloting, and

technology

state/loca

accelerators,

and other

research activities commercialization activities commercialization infrastructure

1 from these enterprises

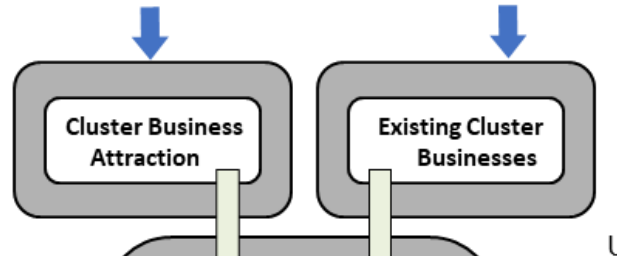

University

Participation in networking and cluster support

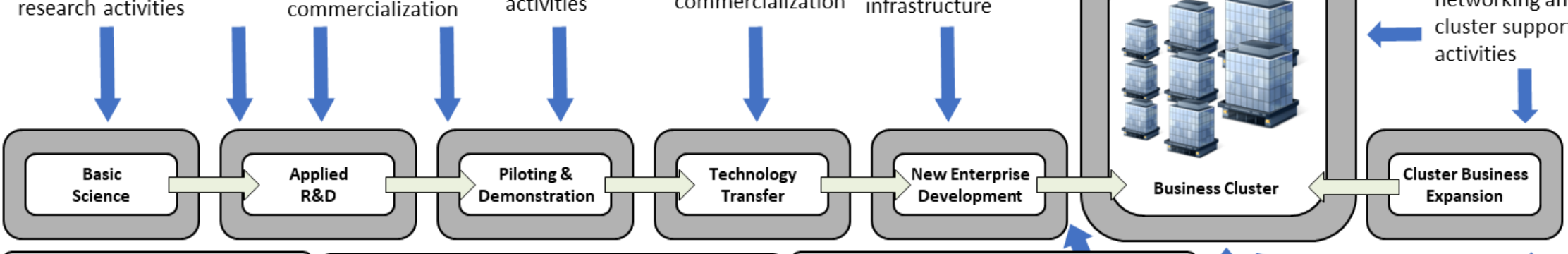
activities Research phase Development phase Commercialization phas

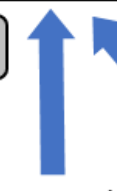

University education and workforce

Feedback:

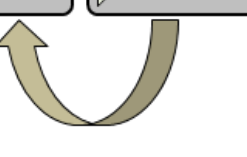

Basic research needed for discovery

- Concept fails in scale-up and testing - return for further research

- Investigation of new solutions to identified challenges
Feedback:

Applied R\&D for new or - Refinements to design

refined product

Changes to improve IP

positioning signals based on cost/market

signals

- Changes for new

unanticipated

applications
Infrastructure and facilities to house science and science and
technology-base new and expanding business enterprise. For example,

university research and science parks. development to guidance on sustaining positive government, regulatory and business climate to meet competitive cluster needs 


\section{Symbiotic relationship between university and industry R\&D}

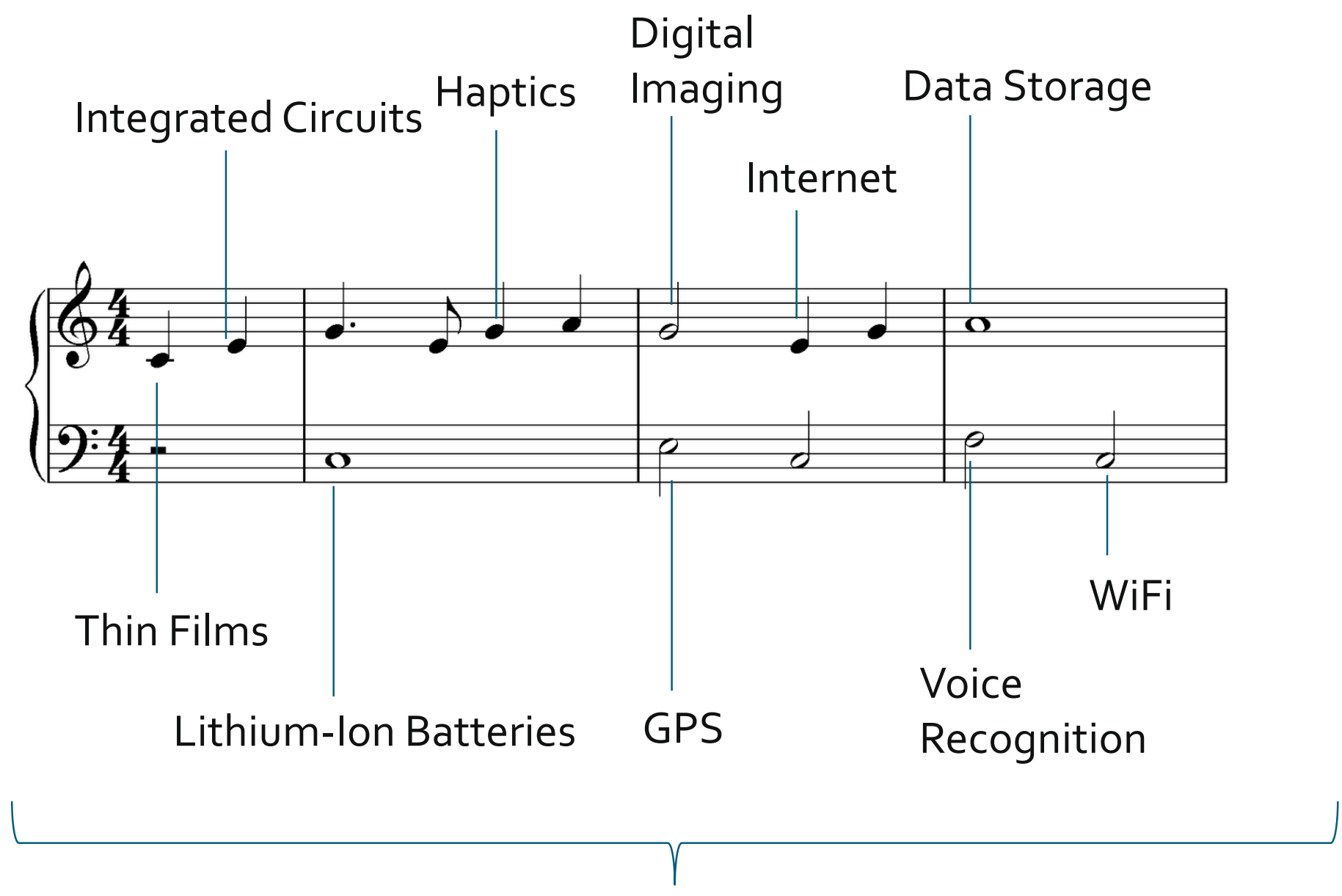

Like notes building upon notes to build a song, research discoveries build upon research discoveries to create novel products and technologies. The result, in this case $=$ Smart Phone.... 


\section{Engineering Impacts: Background and Characteristics}




\section{Engineering Education and Academic Research in the U.S.}

-2015-16 Academic Year Degrees Awarded*:

- Bachelors $=112,721$ (90.4\% U.S. permanent resident)

- Masters = 62,596 (58.1\%)

- Doctoral = 11,654 (45.2\%)

- + Engineering Technology Degrees = 7,241 (94.2\%)

- Engineering academic research expenditures = $\$ 8.9$ billion*

- Starting salaries**:

- Bachelors range $\$ 64 \mathrm{k}$ (Indl/Mfg Eng) to $\$ 68 \mathrm{k}$ (Chem Eng)

- Masters range $\$ 75 \mathrm{~K}$ (EE) to $\$ \$ 80 \mathrm{k}$ (Software Eng) 


\section{Engineering at the}

core of major academic research advancement. The example of Indiana's research university ecosystem

Indiana University IUPUI Purdue University University of Notre Dame

Publications cluster analysis by TEConomy Partners.
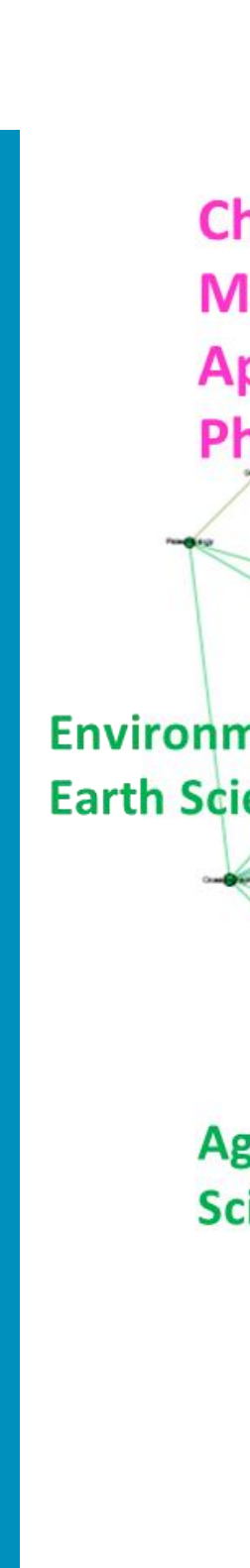

Environmental \&

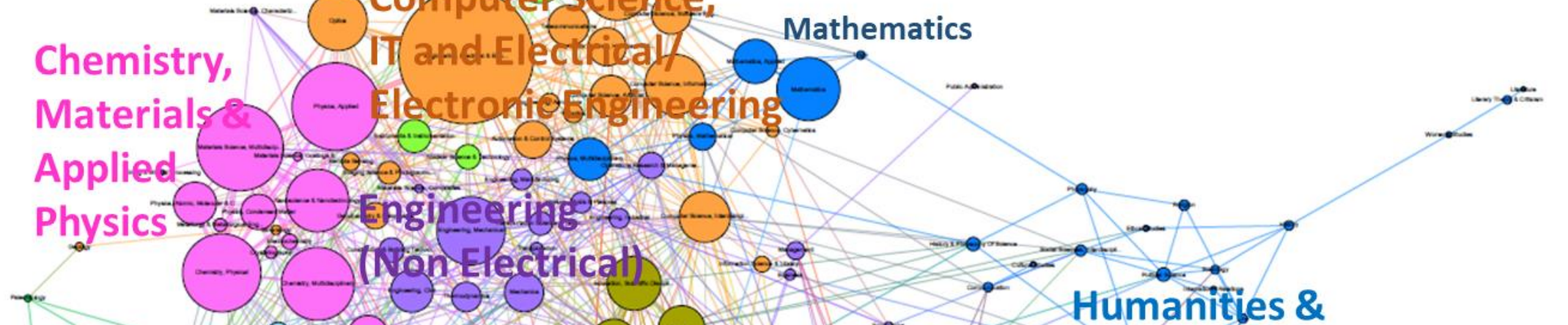

Earth Scienceso

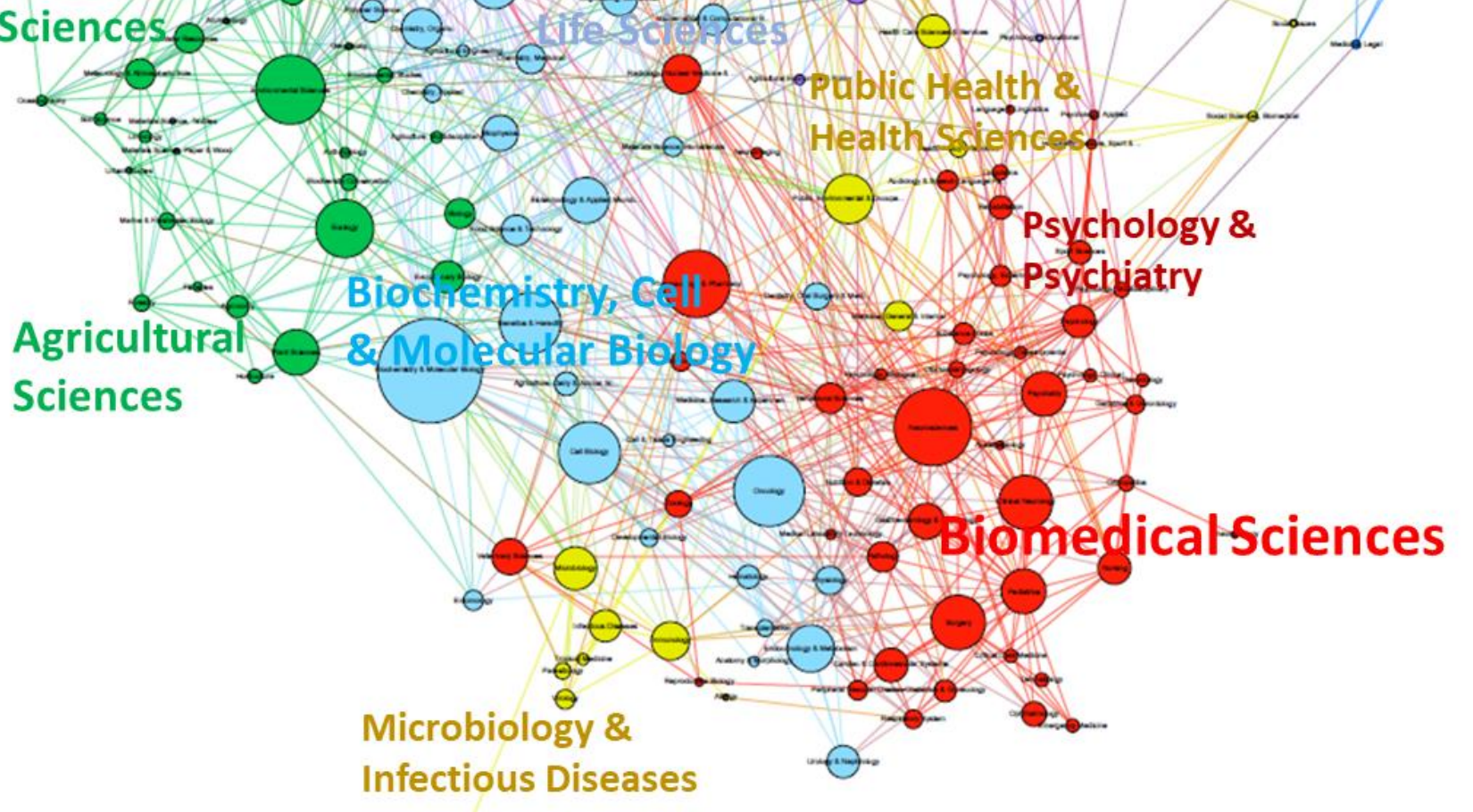




\section{Engineering \&}

Computer Science $2^{\text {nd }}$ Largest Cluster for New Journals.

\section{Global Analysis of the} Speciation of New Academic Journals (2000-2013). Simon Tripp \& Martin Grueber.

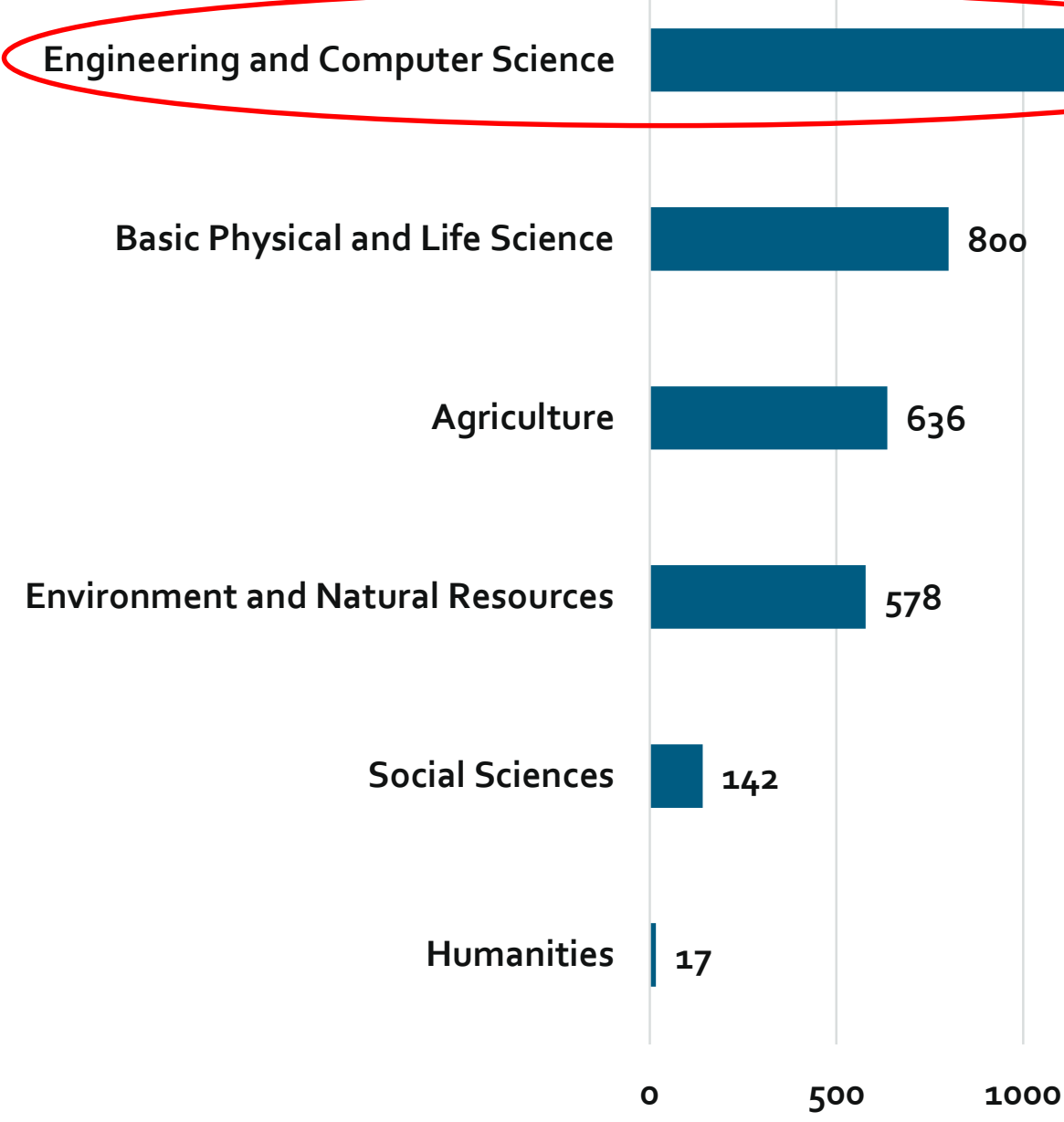

1000
1162

- 7,496 new journals.

- Average of 535 completely new journals "speciated" annually.

- Average of almost $\underline{1.5}$ completely new journal mastheads per day. 


\section{Engineering} capabilities are at the heart of tackling most major global grand challenges.

Simon Tripp, analysis of global challenge domains and connectivity to technologies.

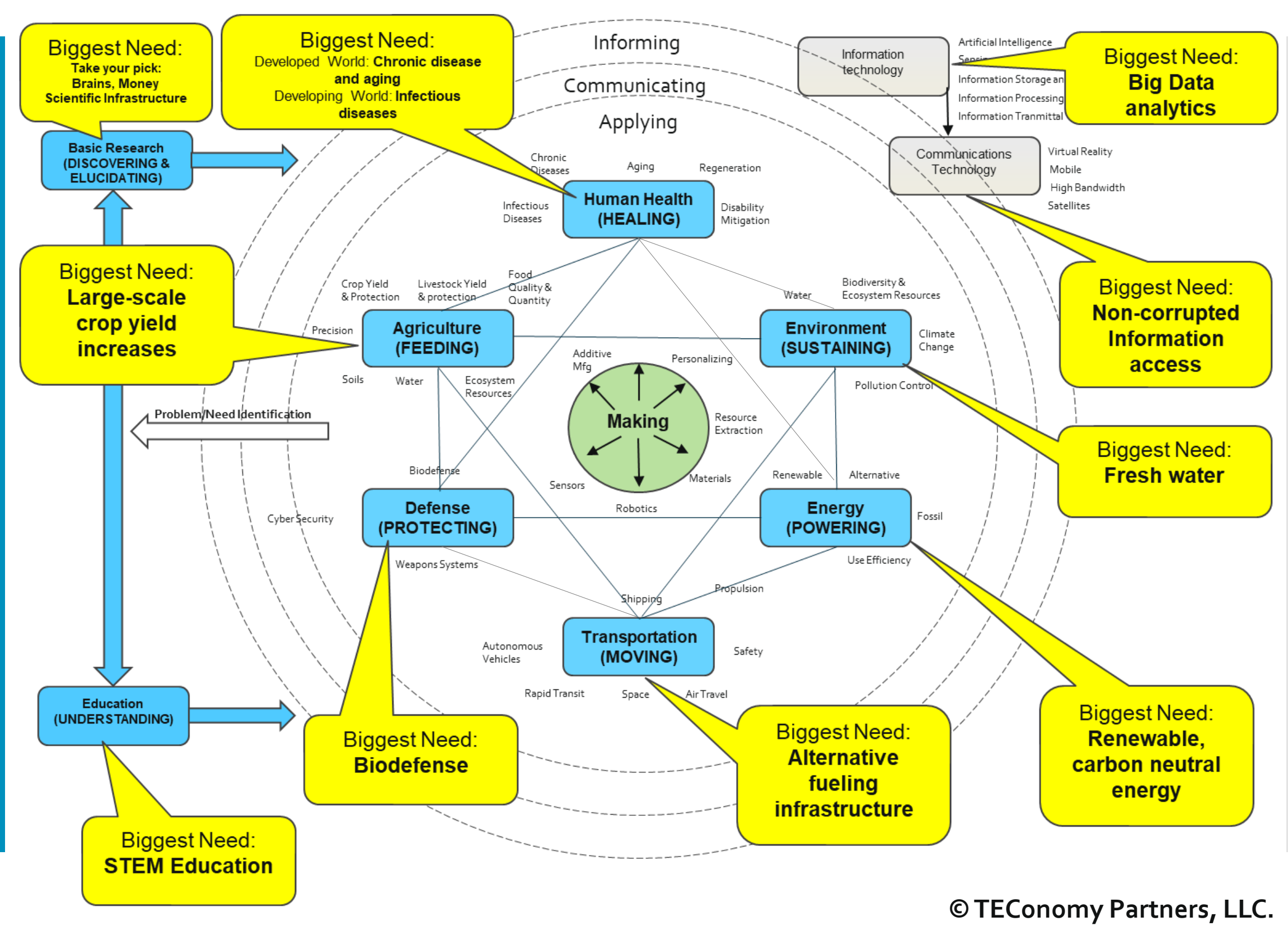


UK Study by

Royal

Academy of Engineering
- Created an Engineering Index (measuring strength in engineering across 9 variables for 99 countries) and compared to "GDP per Capita" and "Investment per Capita". Found:

- "A strong positive link between engineering strength and both economic indicators."

- U.S. rated 17th with Engineering Indicator score of 60\%

- Highest was Sweden with 75\%, followed by Denmark, The Netherlands, Germany and Japan.

- The Republic of Korea has highest R\&D as a percent of GDP at $4 \%$, vs U.S. at $2.7 \%$ (ranked $8^{\text {th }}$ ) 


\section{Major Innovation Frontiers and Disruptive Technologies.}

\section{Engineering is engaged in all.}

Classification of Disruptive Technologies byTEConomy Partners.

\begin{tabular}{|l|l|l|}
\hline \multicolumn{1}{|c|}{ Biological } & \multicolumn{1}{|c|}{ Physical } & \multicolumn{1}{c|}{ Cyber/Digital } \\
\hline a. Next-Gen Sequencing & a. Additive Manufacturing & a. Artificial Intelligence \\
b. Gene Editing & b. Advanced Robotics & b. Virtual and Augmented \\
c. Synthetic Biology & c. Autonomous Vehicles & Reality \\
d. Regenerative Medicine & d. Energy Storage & c. Cyber Security \\
and Tissue Engineering & e. Alternative and & d. Cloud \\
e. Metabolic Engineering & Renewable Energy & e. Big Data Analytics and \\
f. Nanomedicine & f. Advanced Materials & Associative Intelligence \\
g. Cyber-biological & g. Electric Vehicles & f. Natural Language \\
systems/implantables & h. Alternative Mass Transit & Processing \\
\multicolumn{2}{|c|}{} & g. Quantum Computing \\
\multicolumn{2}{|c|}{ The U.S. cannot compete and realize the } & h. Information Validation \\
true opportunity inherent in any of these & i. Edge Computing \\
without R\&D contributions across a range & j. Mobile Internet \\
of engineering disciplines, and without a & k. Internet-of-Things \\
steady output of qualified engineering & l. Cryptocurrencies and \\
\hline
\end{tabular}
graduates. 


\section{Colleges of Engineering and the Critical Supply of our Future Workforce}

- Recent analysis by Mark Muro et al at Brookings examined changes in the digital content of 545 occupations embracing 90\% of the U.S. workforce since 2001. Among their findings:

- Digitalization is associated with increased pay for many workers and reduced risk of automation

- Digitalization is changing the skills needed to access economic opportunity

- Changes have been striking. By 2016, the share of employment in occupations with high digital content...more than tripled, from 4.8 to 23 percent of employment

- Employment in occupations with low digital scores...declined precipitously, from 55.7 to 29.5 percent. 


\section{Conducting an Economic and Functional Impact Analysis}




\section{Conducting an Economic and Functional Impact Study}

- Difference between backward linkage (expenditure impacts) and forward linkage impacts (functional impacts).

- Input/output analysis for measuring direct, indirect and induced impacts on output, employment, value added, tax base.

- Multiple spatial scales possible

- Starts with mapping out impact domains associated with the college

- Will have multiple audiences, so must present easily understood and well rounded assessment, including case studies/examples

- TEConomy also examines opportunities to increase impacts and enhance regional development ecosystem

- Can be combined with core competency assessment, TBED platform identification, strategic planning etc. 
Enhanced economic impacts via new, expanding and retained companies

Colleges of Engineering.

Structure of Functional Impacts
IP, process and product improvement, and knowledge transfer to local, regional or state industry

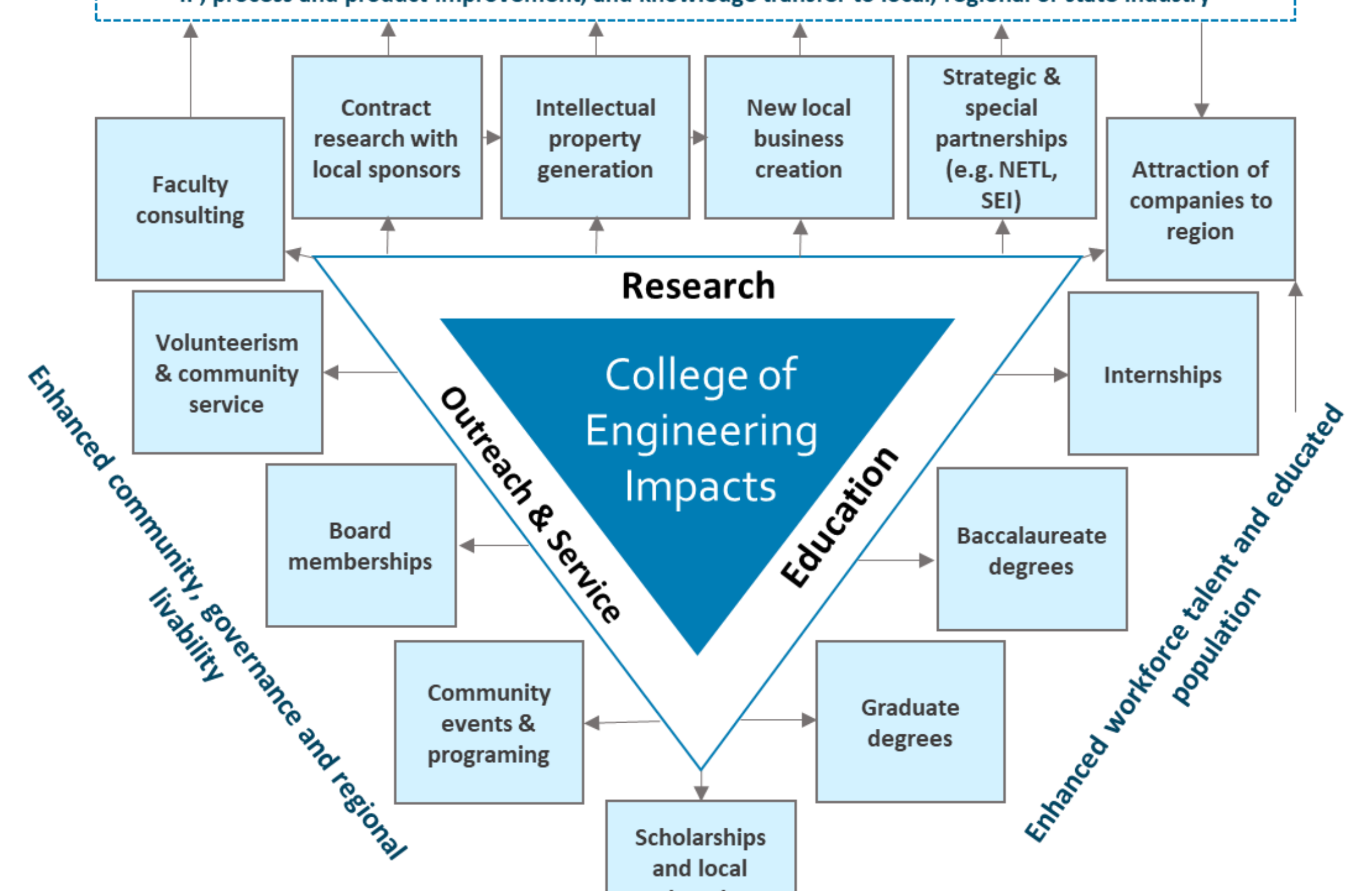


OSU Extension

Spending and

Functional Economic

and Social Impacts

\section{Undertaking}

economic and functional impact analysis.

Starts with mapping out impact domains

\section{Grants/}

Contracts/

Gifts

Federal funds

to OSU

Extension

osu

Ohio County

support funds

State of Ohio
support funds

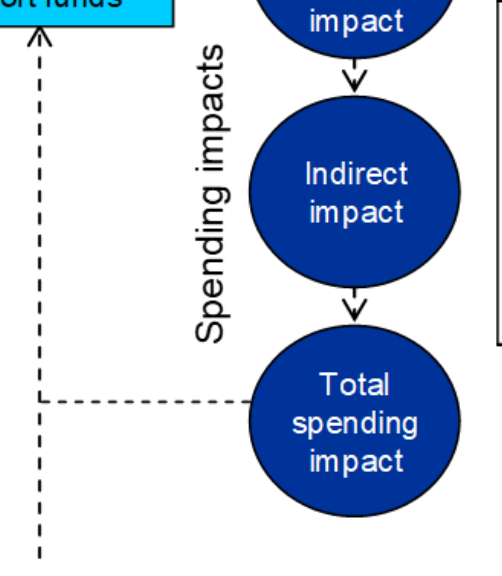
Extension
Benefits

Impacts

\begin{tabular}{|c|c|}
\hline rung & IItS \\
\hline $\begin{array}{l}\text { Emerging trends \& } \\
\text { needs }\end{array}$ & $\begin{array}{l}\text { Intelligence to drive applied OSU research to } \\
\text { meet emerging Ohio ag./env. needs. }\end{array}$ \\
\hline $\begin{array}{l}\text { Technology education } \\
\text { and introduction }\end{array}$ & $\begin{array}{l}\text { Enhanced productivity and income streams, } \\
\text { for Ohio's ag./env. producers and processors }\end{array}$ \\
\hline $\begin{array}{l}\text { Techniques and skills } \\
\text { education }\end{array}$ & $\begin{array}{l}\text { Enhanced productivity and income streams, } \\
\text { for Ohio's ag./env. producers and processors }\end{array}$ \\
\hline $\begin{array}{l}\text { New crops and } \\
\text { products/diversification }\end{array}$ & $\begin{array}{l}\text { Open new markets, generate new revenue } \\
\text { streams, enhance competitiveness. }\end{array}$ \\
\hline $\begin{array}{l}\text { Marketing and business } \\
\text { development }\end{array}$ & $\begin{array}{l}\text { Open new markets, generate new revenue } \\
\text { streams, enhance competitiveness. }\end{array}$ \\
\hline
\end{tabular}

Jobs, economic

Jobs, economic

and government

revenue

and Natural

Resources

Community

Development

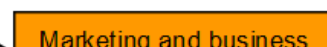

streams, enhance competitivenes

4-H Youth

Development

Marketing and business
development

Attract and develop new economic

development engines for communities

Maintain and enhance community economic base and economic development

Enhanced employment ops and productivity

Economic/community development strategy

and sustainable development leadersh

Analysis and solutions to improve

communities

Family and

Consumer

Sciences

Jobs, economic

output, income

and government

revenue

Enhanced Ohio

community

sustainability (1)

\begin{tabular}{|l|}
\hline Improved social conditions and economics \\
\hline Individual and family well-being \\
\hline Enhanced public health \\
\hline Improved economic sustainability \\
\hline Reduced social and economic problems \\
\hline $\begin{array}{l}\text { Youth motivation, enhanced educational } \\
\text { attainment, and reduced social problems }\end{array}$ \\
\hline Improved personal conditions and economics \\
\hline $\begin{array}{l}\text { Maintain ag. and env. sector sustainability } \\
\text { through multiple generations in addition to } \\
\text { more general workforce skills development }\end{array}$ \\
\hline \hline $\begin{array}{l}\text { Youth leadership capability, citizenship, and } \\
\text { public service }\end{array}$ \\
\hline
\end{tabular}

Enhanced Ohio

community and

family

sustainability

Reduced

negative costs

Jobs, economic

output, income,

and government

revenue 


\section{Undertaking economic and functional impact analysis.}

Starts with mapping out impact domains

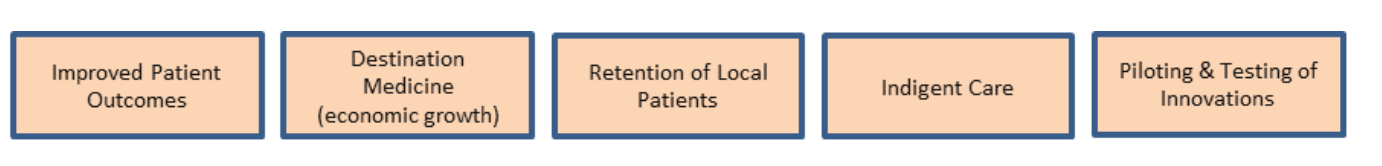

Mayo Clinic

Functional Impact

Roadmap

$\square$ = Functional Impact

$\square$ = Outcomes/Benefits

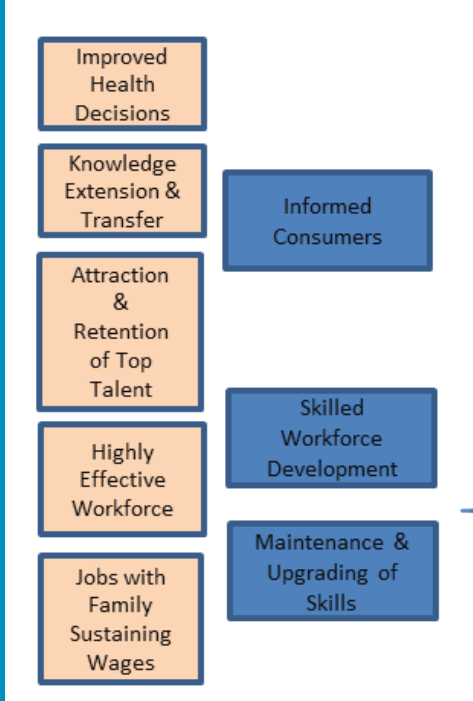

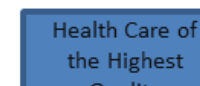

Care of High
Complexity

Access to
Latest Trials

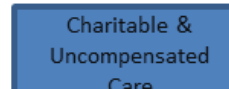

Early Adoption
of Medical
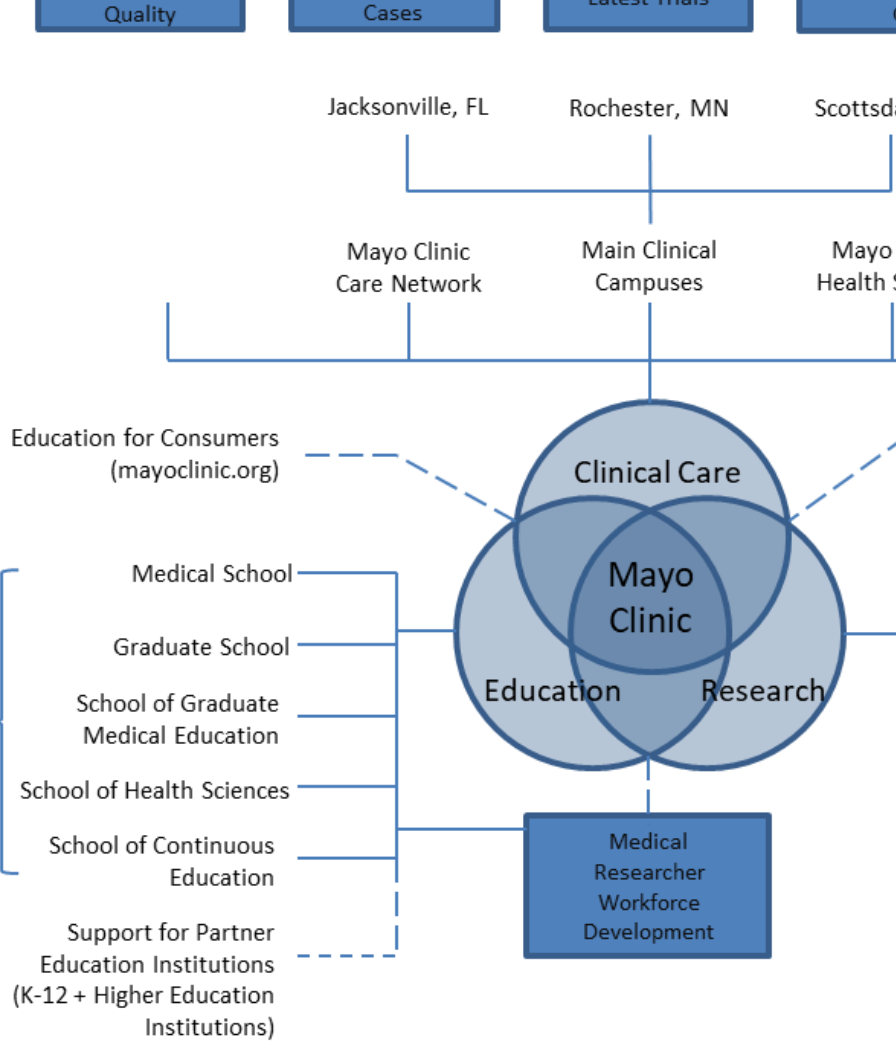

Other Attributes and Impacts

- Image "halo"/regional and state marketing effect

Community service

Charitable givin

Commitment to sustainability

- Others?

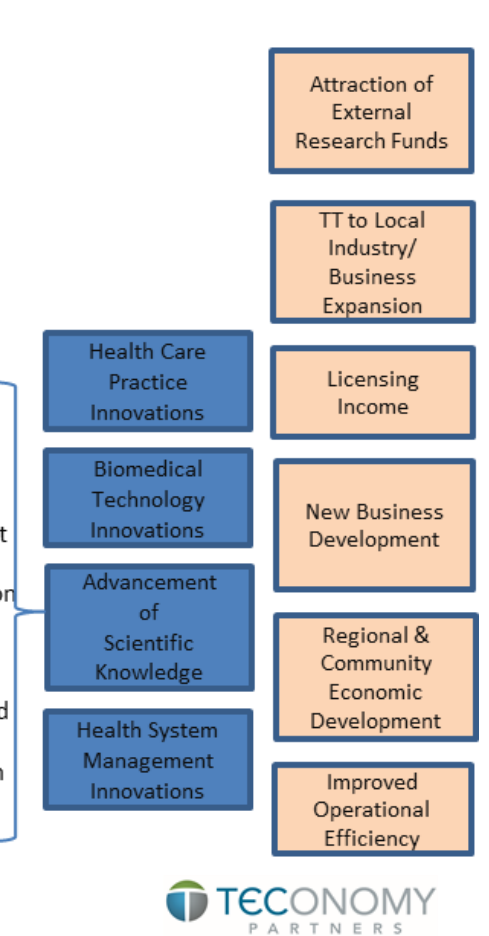




\section{University of Missouri Extension. Functional Impact Coverage.}

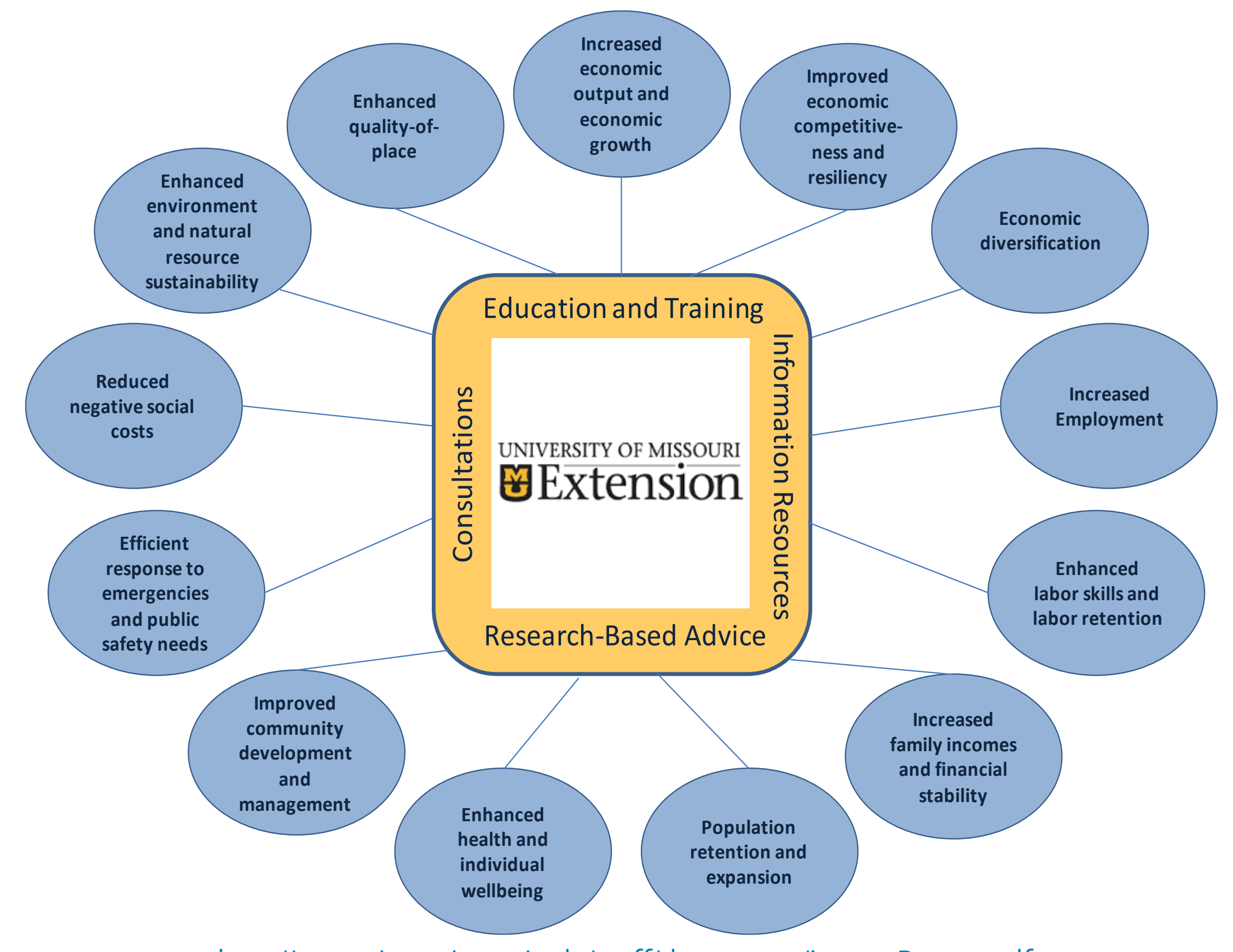


The university research enterprise is highly dependent on funding derived from external sources outside the control of the university

\section{Also important to discuss threats.}

A series of challenges, or "tensions" are facing U.S. research universities and colleges of engineering.

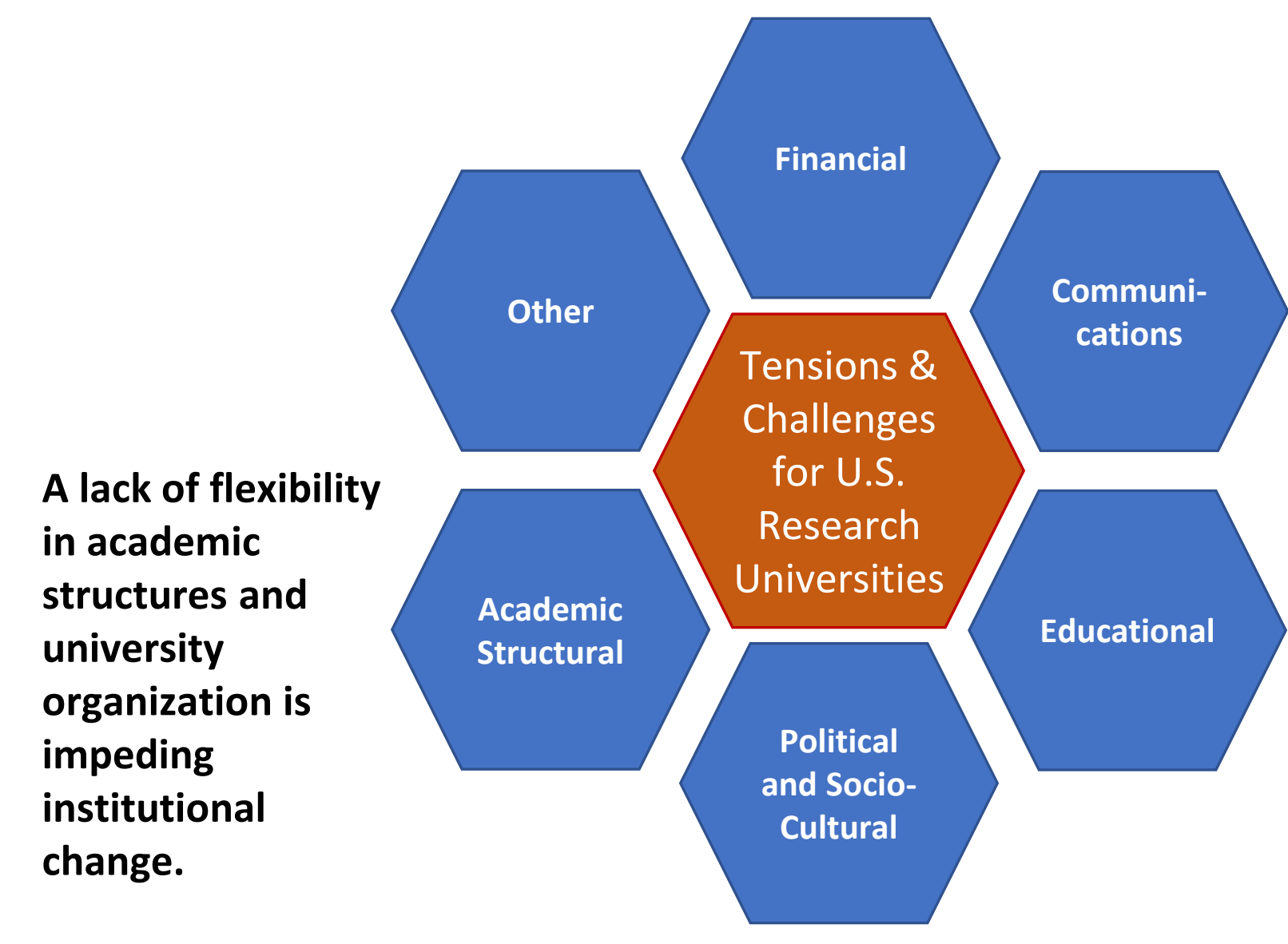

Political and social ideologies are presenting barriers to the rational pursuit of knowledge and impeding the performance of research.
Public

understanding is eroding and norms of information transfer and content reliability are under threat.

K-12 and STEM education in the U.S. are underperforming, leading to insufficient "input" of human capital to the higher education system. 


\section{Conclusions (1)}

- Engineering is key to solving challenges, and realizing opportunities, at a global and local scale.

- Areas of distinct opportunity for the U.S. economy are rooted in engineering progress and innovation.

- The theme of transdisciplinarity makes engineers a crucial component of R\&D teams across most frontier areas of science and technology.

- Disruptive changes are coming, and colleges of engineering are key to realizing these as areas of opportunity and competitive advantage for the U.S., rather than threats.

- Colleges of engineering have diverse impacts across social/private and market/non-market dimensions. 


\section{Conclusions (2)}

- Colleges of engineering are a critical component for a complete technology-based economic development ecosystem.

- STEM education and engineering/digital skills are crucial for workforce preparedness and high paying future jobs in the U.S.

- Explaining the economic and functional impacts of colleges of engineering to multiple stakeholders is critically important. Different factors will hold appeal to different audiences.

- The U.S. is far from alone in developing world-class engineering education and R\&D. Continued investment in both is required to sustain the competitiveness of the U.S. and create a bright economic future for U.S. workers and families. 


\section{(1) TECONOMY \\ P A R T N E R S}

Innovating Tomorrow's Economic Landscape

TEConomy Partners is a global leader in research, analysis and strategy for innovation-based economic development. Today we're helping nations, states, regions, universities, and industries blueprint their future and translate knowledge into prosperity.

\section{Contact:}

Simon Tripp, Principal and Senior Director Email: tripps@teconomypartners.com

Phone: 412-276-1986 